logos_i_ethos_2016_(43)_numer_specjalny_2, s. 89-107

DOI: http://dx.doi.org/10.15633/lie.1962

Виктория Кравченко

\title{
Философия П. Я. Чаадаева как современная теоретическая проблема
}

Все более глубоко постигая самобытность русской философии, многие современные исследователи считают, с теми или иными оговорками, что ее истоки находятся в наследии П. Я. Чаадаева. Личность и творчество Чаадаева сегодня воспринимаются в качестве некого философского архетипа русской мыслительной традиции. Этот архетип можно

Виктория Кравченко - доктор философских наук (1998 - СПбГУ; 2000 - НАН Украины, Киев). Профессор Московского авиационного института (Национального исследовательского университета). Круг научных интересов: история русской философии, философия религии и религиоведение, символизм, русский космизм, теория культуры, философско-психологические аспекты виртуалистики, история и философия науки, философия литературы и художественного творчества. было бы охарактеризовать так:

религиозно-философский проект (как правило, лишь намеченный, но всегда недостроенный, незавершенный), претендующий на глобальный (вселенский, всечеловеческий, космический) смысл поднятых в нем проблем и предполагающий коренную роль России в их решении.

При всей значимости творчества Чаадаева для становления и развития русской философии, признаваемой не только российскими, но и зарубежными историками философии ${ }^{1}$, современные русские философы не уделяют должного внимания личности и наследию Чаадаева. До сих пор единственной добротной монографией

1 М. О. Гершензоном, В. В. Зеньковским, Г. Флоровским, Х. Фальком, Ш. Кенэ, Ч. Макнэлли и др. 
о философе остается работа М. О. Гершензона начала XX века ${ }^{2}$, а ведущими современными биографами и интерпретаторами Чаадаева являются филологи ${ }^{3}$.

Существуют ли объективные причины для проявления такого «цехового» настороженного отношения к Чаадаеву в современном философском сообществе? Представляется, что основными причинами являются: необычность формы чаадаевских произведений, множество мифов о личности философа и мифов, созданных им самим, а главное - откровенный новорелигиозный характер его фундаментальных идей, и даже явно мистический уклон его некоторых построений. Таким образом, в философии Чаадаева сконцентрировано слишком много сложнейших проблем, которые пока являются неподъемными для все еще ищущей свой путь постсоветской российской философии. Попробуем очертить основные теоретические проблемы философии П. Я. Чаадаева.

Рассмотрим сначала форму философских сочинений Чаадаева. Зададим себе вопрос: почему мыслитель для изложения своих основных и важнейших идей избрал такой специфический литературный жанр, как письма, проигнорировав уже привычные и признанные философские формы - трактата, статьи, эссе?

И это продуманная и намеренная тактика - потому что сотрудничество с печально известным журналом «Телескоп» началось ранее первого философического письма - вполне обычной статьей, хотя также связанной с эпистолярным жанром ${ }^{4}$. Но о ней сегодня пом-

2 М. О. Гершензон, П. Я. Чаадаев. Жизнь и мышление, Санкт-Петербург 1908.

3 А. А. Лебедев, Чаадаев, Москва 1965; Б. Н. Тарасов, Чаадаев, Москва 1990; Б. Н. Тарасов, «Тайна человека» и тайна истории. Непрочитанный Чаадаев, Москва 2012.

4 Примечательно, что статья является анонимной. В примечании к публикации указывается: «Издатель получил сии отрывки при следующей записке: “М(илостивый) Г(осударь)! Препровождая к вам некоторые отрывки из переписки одного из наших соотечественников, для помещения в вашем журнале, считаю нужным сказать об них несколько предварительных слов. Переписка сия представляет развитие одной полной, глубоко обдуманной системы. Предлагаемые здесь отрывки, не смотря на разнородность их предмета, проникнуты также одною основною мыслию. И эта внутренняя связь их, при внешнем разнообразии, есть именно то, что дает им особенную цену. [...] [В] оригинале они отличаются 
нят только специалисты, а главное - на эту первую статью никто из современников внимания не обратил, хотя издатель, возможно, действительно надеялся заинтересовать читателя «логогрифом» и привлечь его внимание к возвышенным проблемам бессмертия души.

Уже в XVIII в. в Европе были широко распространены художественные произведения эпистолярного жанра. В России пушкинской поры все читали роман Персидские письма Ш. Л. де Монтескье, адресованные госпоже Каландрини ${ }^{5}$. Также было известно множество подражаний: Турецкие письма Пуллена де Сен-Фуа (1730-1732), Еврейские письма маркиза д’ Аржана (1739-1742) и пр. Среди подобных произведений можно отметить романы, написанные женщинами. Скажем, Письма перуанки мадам де Графиньи (1747) и, конечно, знаменитый в России роман Валери Варвары-Юлии Крюденер, писательницы, мистика и великосветской дамы, одно время оказывавшей серьезное влияние на императора Александра I. Зачастую подобные литературные сочинения включали новые религиозно-философские идеи.

Чаадаев не был склонен к созданию художественной прозы; он начал развивать жанр философских писем, сохранив уже привычные литературные приемы. В посланиях, адресованных даме, он живо и непосредственно обсуждал идеи, далекие от общепринятых и официально-поддерживаемых взглядов. Понятно, что как и в случае с подобными литературными произведениями, общественную и официальную реакцию на новаторские и свободные философские «штудии»-размышления предсказать было фактически невозможно...

еще необыкновенною изящностию языка. В переводе утрачено это достоинство, которого одного было бы достаточно, чтобы заинтересовать наших читателей. Теперь остается в них, по крайней мере, интерес логогрифа: отгадать, что может быть общего между архитектурой и бессмертием души». П. Я. Чаадаев, Нечто из переписки NN, «Телескоп» 11 (1832), с. 347.

5 Первое издание Персидских писем Монтескье на французском вышло в Амстердаме в 1721 г. Первым русским переводчиком этого романа считается Антиох Кантемир, но его труд, к сожалению, не сохранился. Первые русские издания Персидских писем появились в конце XVIII в. (в переводах Ф. Поспелова 1789 и Е. Рознотовского 1792 г.), а в отрывках публиковались в русских журналах уже с 1782 г. 
Обратим внимание на то, что заданная в эпистолярной форме интимность, частный, личный характер обращения, уводит от привычного философского диалога, придавая глубоким и оригинальным суждениям оттенок намеренного красования автора, даже чрезмерного пафоса, а часто - профетизма. Критический настрой чаадаевского философского высказывания одновременно возбуждает ответную реакцию, но и сбивает с основных тезисов на частности, отводя взгляд от коренных, фундаментальных проблем.

То, что в философском трактате читается как выстраивание теоретической позиции, в эпистолярной форме воспринимается как сугубо личная точка зрения, претендующая на частный отклик, на такое же личное и откровенное монологичное суждение. Это явный и намеренный уход от сократовского диалога, как публичного философского дискурса, сохраняющего свой характер общего обращения к любому читателю в обычных философских сочинениях. Эпистолярный жанр - это обмен законченными монологическими посланиями; при этом любой читатель письма, кроме адресата, ставится в двусмысленное, безмолвное и безучастное положение наблюдателя-свидетеля.

Как первые опубликованные отрывки из переписки, так и Философические письма - это заявка на другой способ философствования, когда истина не добывается в живом обсуждении, а предполагается уже существующей за пределами непосредственного общения (повторим сопроводительные слова к издателю первой переписки: «развитие одной полной, глубоко обдуманной системы»). Результат чтения посланий Чаадаева - в самостоятельном освоении адресатом уже готовых авторских положений, изложенных заведомо несистематически, прихотливо, иногда чрезмерно эмоционально, как бы даже не с целью убедить, а просто высказаться и снять авторское интеллектуальное напряжение.

Эпистолярность трудов Чаадаева - не просто литературный прием; это продуманный способ философствования, требующий не собеседника, а современного читателя как безмолвного воспринимателя информации, с гипотетической перспективой уточнения неясных 
деталей при личной встрече, которая заведомо предполагается не свободным обсуждением поднятых проблем, а лекцией, в ходе и по завершении которой вряд ли предусматривается критика.

В определенном смысле это - интеллектуальный вызов, философско-литературный аналог так часто описываемой современниками чаадаевской надменной позы, в конце концов - литературнофилософская провокация, рискованный ход болезненного самоутверждения...

Публикация первого Философического письма - это резкий и непредсказуемый философский поступок Чаадаева, полностью аналогичный его скандальному выходу в отставку ${ }^{6}$, но с более неожиданными и драматичными последствиями. Так же как высокомерно-глупое военное начальство, он презирал надменных «властителей дум», претендовавших на обладание окончательной истиной. И он подстроил еще одну «штуку» с блюстителями социальных устоев и религиозно-философских идеалов, теша свое уязвленное (больное?) самолюбие, невзирая на катастрофические последствия. И если, отказавшись от продолжения военной карьеры, по выходе в отставку он только не получил положенный ему следующий военный чин, то после социально-философской «штуки» он едва всю свою жизнь не отправил под откос. Но возможно, вспоминая знаменитую формулу гениального русского

6 До сих пор реальные причины отставки Чаадаева неясны, а для его современников добровольная отставка офицера буквально накануне получения им следующего чина стала подлинным шоком. Не вдаваясь в рассмотрение противоречивых фактов и документов, остановимся на характерной фразе Чаадаева из его письма 1821 г. тетушке, княжне А. М. Щербатовой: «Я действительно должен был получить флигель-адъютанта по возвращении Императора, по крайней мере по словам Васильчикова. Я нашел более забавным презреть эту милость, чем получить ее. Меня забавляло выказывать мое презрение людям, котоpые всех презирают. [...] Должен вам признаться, что я в восторге от того, что уклонился от их благодеяний [...]. Нет на свете ничего более глупо высокомерного, чем этот Васильчиков, и то, что я сделал, является настоящей штукой, которую я с ним сыграл. Вы знаете, что во мне слишком много истинного честолюбия, чтобы тянуться за милостью и тем нелепым уважением, которое она доставляет. [...] Я предпочитаю позабавиться лицезрением досады высокомерной глупости» (курсив В. К.). П. Я. Чаадаев, Письма, в: П. Я. Чаадаев, Полное собрание сочинений и избранные письма, т. 2, Москва 1991, с. 14-15. 
поэта, Чаадаев по складу своего мятежного духа намеренно искал «бури», обретая таким образом необходимый ему творческий «покой»?..

Мы сегодня можем говорить о первом проявлении русского творческого «авангардизма», о первой «пощечине общественному вкусу», которая автору обходится значительно дороже и больнее, чем провоцируемому им обществу, но запоминается навсегда, что, может быть, и является главным результатом акции...

Чаадаев вышел к читателям с готовой продуманной философской программой ${ }^{7}$, которую он должен был продвигать, используя наиболее эффективные инновационные методы ${ }^{8}$. Он не хотел ждать, пока одинокие высоколобые интеллектуалы, подобные ему, месяцами будут вдумчиво и критично вчитываться в его философский труд, потом годами полемизировать в специальных журналах в предвкушении выхода его фундаментальной монографии, чтобы через десяток лет вынести свой вердикт. Современники сравнивали чаадаевскую публичную акцию с выстрелом в ночи, а мы, чтобы понять суть произведенного им эффекта в тогдашнем обществе, можем провести параллель с современным нам флеш-мобом, или скорее с интеллектуальным вариантом компьютерного троллинга

7 См. в письме к А. С. Пушкину 1831 г.: «Вам хочется потолковать, говорите вы: потолкуем. [...] У меня только одна мысль, вам это известно. Если бы невзначай я и нашел в своем мозгу другие мысли, то они, наверное, будут стоять в связи со сказанной: смотрите, подойдет ли это вам». П. Я. Чаадаев, Письма, ор. cit., с. 69. О характере этой «одной мысли» прямо писал близкий друг Чаадаева А. И. Тургенев к своему брату Н. И. Тургеневу в письме от 2 июля того же 1831 г.: «Был я у П(етра) Я(ковлевича) [...] я увидал, что одна мысль, религиозная - о коей он пишет - слишком исключительно занимает его. [...] Книг у него много, и все в роде религиозном...». Комментарии и примечания, в: П. Я. Чаадаев, Полное собрание сочинений и избранные письма, т. 2, ор. сіt., с. 307.

8 Так, в письме к Пушкину от 17 июня 1831 г., Чаадаев просит поскорее вернуть ему свою рукопись и подчеркивает: «Вы знаете, какое это имеет значение для меня? Дело не в честолюбивом эффекте, но в эффекте полезном. Не то чтоб я не желал выйти немного из своей неизвестности, принимая во внимание, что это было бы средством дать ход той мысли, которую я считаю себя призванным дать миру; но главная забота моей жизни - это довершить эту мысль в глубинах моей души и сделать из нее мое наследие». П. Я. Чаадаев, Письма, op. cit., с. 67. 
в совокупности с активной блогерской атакой и удачными постами и перепостами в Инстаграм.

Выбрав как будто бы мелкие философские формы - письма, наброски, «мысли и размышления», заметки и т.п., по существу, Чаадаев твердо отстаивал собственную, непререкаемую философскую позицию; он выстроил себе философский постамент, с которого, как жрец, вещал истины, не подлежавшие обсуждению, а требовавшие от воспринимающих усвоения готовых идей и применения их к каждой отдельной личной ситуации. Предполагалась ли критика? Возможно, не менее эмоциональная и резкая, чем чаадаевские выпады, тем более, что философские проблемы, изложенные в частной переписке, заведомо выносились за рамки профессиональной полемики. Реально наступивших катастрофических последствий своего поступка автор, конечно, предполагать не мог.

Он ведь испытал гонения не за философию, а за веру. Причем, по недоразумению, - за симпатии к католичеству со стороны официального православия. В действительности, Чаадаев проповедовал новое христианство в предельно общей его трактовке, которая включала, как выяснялось в последующих письмах, и мусульманство ${ }^{9}$, и иудаизм, в той степени, в которой те связаны со Словом Священного Писания. Правда, это христианство категорически исключало протестантизм, слишком свободно трактующий Писание.

О содержании чаадаевской философии, по сути, уже написано довольно много, но явно недостаточно. В первую очередь, потому что сама чаадаевская философия трактуется как особая (русская) разновидность западной философии. А она другая, от западной отталкивающаяся, к восточно-христианской традиции примыкающая исподволь, представляя собой, по существу, первое русское свободное

9 Так, в Письме Седьмом он писал о «благе, вытекшем для человечества» из религии Магомета (уничтожение многобожества, распространение идеи единого Бога, объединение людей); и далее мы читаем: «Исламизм есть одно из самых замечательных проявлений общего закона, судить о нем иначе - значит не понимать всемирное влияние христианства, от которого он происходит».). П. Я. Чаадаев, Философические письма, в: П. Я. Чаадаев, Полное собрание сочинений и избраннье письма, т. 1, Москва 1991, с. 429. 
религиозно-философское учение христианского толка, возможно, будучи непосредственным предтечей будущей философии свободной теургии, свободного духа или чего-нибудь в подобном ключе.

О философско-просветительской активности Чаадаева необходимо сказать отдельно, поскольку для сферы философского творчества того времени она была столь же оригинальна, сколько и его теоретическая деятельность. Прекрасно зная ту культурную среду, в которой он мог быть реально услышан, Чаадаев максимально эффективно использовал доступные ему средства для продвижения своих идей. Он поднял частную переписку на высочайший уровень философствования, учитывая распространенную тогда в образованной среде традицию передавать другим для чтения свои письма, копировать и обсуждать интересные темы как в последующих письмах, так и при личных встречах. И даже эссе Апология сумасшедщего, как будто бы нарушающее эпистолярную традицию, все равно сохраняет интонацию личного обращения и самооправдания, категорически отличаясь от классических философско-теоретических трактатов.

Чаадаев, необычным способом распространяя свои религиозно-философские идеи ${ }^{10}$, вольно и невольно способствовал созданию миба о себе, а также создавал мифы в своих работах.

В объективном плане, миф о нем естественным образом складывался на яркой биографической основе: легендарный образ бравого гусара, бесстрашного и героического участника войны 1812 г.; блестящий завсегдатай знаменитых светских салонов; соратник масонов и декабристов, наконец, близкий друга А. С. Пушкина. Затем

10 Заметим, что в изобретении новых способов самопропаганды и ускоренного продвижения своих идей Чаадаев был не так уж оригинален и успешен. В александровскую эпоху уже упоминавшаяся мадам Крюденер шокировала общественность продуманными $\mathrm{PR}$-акциями (спровоцированными и откровенно купленными восторженными отзывами о своих произведениях и общественной деятельности в печати, организацией поддержки своих идей видными европейскими писателями, включая Ж. де Сталь и немецких романтиков, а также - императором Александром I). И хотя ей не удалось увлечь своими идеями Наполеона Бонапарта, Жюли Крюденер, вне всяких сомнений, в своей социальной активности смотрится более смелой и эффективной. 
бурно обсуждаемая в обществе внезапная отставка Чаадаева, его добровольное заграничное изгнание, едва ли не прощание с родиной. Но - неожиданное возвращение и уход в философский затвор, который прерывается громким скандалом по поводу публикации, разгромом журнала, объявлением Чаадаева сумасшедшим. Он вновь отшельник, но странным образом, его не забывают, он становится одним из «властителей дум». Наконец, Чаадаев прерывает свое уединение и вновь оказывается в центре тогдашней светской жизни.

Миф о Чаадаеве создавало его близкое окружение, те, кто непосредственно общался с философом. Для них он был безусловным авторитетом, увлекательным собеседником, а главное - он пробуждал необыкновенные мысли и идеи, творческие импульсы, возвышенные идеалы. Они угадывали в Чаадаеве пророческий дар, вполне снисходительно принимали его недостатки, создавая вокруг него ореол гения, непонятого толпой.

При всей приземленности образа Чацкого, лишь в некоторой степени соотнесенного с личностью Чаадаева, А. С. Грибоедов ярко показал несовместимость светских обычаев и духовных устремлений русского философа. Однако бегство Чацкого, ищущего по свету свой душевный «уголок», вовсе не отражает смысл добровольного изгнания Чаадаева и его заграничного путешествия. В действительности, его отъезд был связан с поиском необходимого профессионального общения (скажем, с Шеллингом) и условий для интенсивной творческой работы. При этом, в отличие от Чацкого, Чаадаев не был отвергнут светом и даже вполне вписался в его рамки, причем как по возвращении из заграницы, так и особенно после своего продолжительного басманного отшельничества. Но в светском общении Чаадаев всегда умел сохранять неукоснительную духовную и интеллектуальную независимость, в то же время безусловно оказывая сильное влияние на своих многочисленных собеседников.

О пиетете к Чаадаеву сослуживцев, друзей-декабристов, А. С. Пушкина, Ф. И. Тютчева и многих других уже много написано, потому нет нужды приводить многочисленные свидетельства, 
а достаточно указать на то, что источников и аспектов сотворения мифа о басманном философе было более, чем достаточно.

Осознавал ли сам Чаадаев факт созидания мифа о нем и как он к нему относился? Можно с уверенностью сказать, что философ прекрасно все понимал и, более того, прилагал немало усилий для того, чтобы стимулировать и даже - направить этот многолетний процесс в определенное русло. Как известно, Чаадаев часто сам копировал свои письма к одному лицу, давая читать их другим людям; или писал свои абстрактно-философские заметки в виде писем, содержащих важные для него идеи, и распространял их среди своих многочисленных знакомых. Он стимулировал этот прием пропаганды своих воззрений у друзей, и особенно у своих почитательниц.

Также многозначительным является его анонимное сотрудничество с верным учеником, И. М. Ястребцовым, которое превратилось в прямую диктовку Чаадаевым целой главы книги Ястребцова $\mathrm{O} c u$ стеме наук, приличных в наше время детям, назначаемым к образованнейшему классу общества (1833). Посредством книги своего последователя Чаадаев продолжал распространять свои идеи, тем более, что официально ему было запрещено издавать собственные труды.

Кроме того, известно, что Чаадаев написал письмо (в октябре 1836 г.) от имени своего близкого друга М. Ф. Орлова, по поводу публикации в «Телескопе» скандального письма. Характерно, что он не пытается критиковать содержание своей работы, а от лица друга ставит под сомнение уместность ее публикации именно в 1836 году! ${ }^{11}$ Это письмо осталось неоконченным, но мы не можем считать с полной уверенностью, что подобный «опыт» был единичным...

К намеренной мифологизации Чаадаева посредством переписки можно также отнести и распространение его идей верными последователями. Так, после известной встречи Чаадаева с Шеллингом в Карлсбаде в 1825 г., его русскими друзьями за рубежом был инициирован обмен письмами Чаадаева со знаменитым 
западным философом. Письмо Чаадаева сначала было передано П. А. Вяземскому в Санкт-Петербург, затем И. Гагарин привез его в Мюнхен, передал А. И. Тургеневу в Женеву, а тот, через некую Сильверст, вручил письмо Шеллингу. Позже А. И. Тургенев получил ответ Шеллинга и передал его Чаадаеву ${ }^{12}$.

Какие мифы творил Чаадаев в своей философии? Конечно, об отсталой России. Он прекрасно знал русскую национальную психологию, и всеми силами и средствами пытался растолкать, разбудить отечественную общественную мысль, этого заспавшегося русского медведя, твердо зная, что русские долго запрягают, но быстро едут. Он чувствовал, что исторический момент настал; и именно он, скорее всего, а не декабристы, как думал В. И. Ленин ${ }^{13}$, разбудил А. И. Герцена, который, будучи одним из верных поклонников Чаадаева ${ }^{14}$, зазвонил в свой «Колокол» на всю Европу.

Проблема в том, что Чаадаев также создал мощный и впечатляющий миф о Западе. Это тоже было новаторством, небывалым словом в русской мысли. Русские дворяне, воспитываемые на родине, как иностранцы, жившие «на два мира», привычно преклонявшиеся перед Европой, просто не считали нужным формулировать свое

12 В. Ю. Проскурина, Примечания, в: П. Я. Чаадаев, Сочинения, Москва 1989, с. 616.

13 В знаменитой статье Памяти Гериена (1912) вождь мирового пролетариата писал: «Декабристы разбудили Герцена. Герцен развернул революционную агитацию» (В. И. Ленин, Полное собрание сочинений, т. 21, Москва 1967, с. 261).

14 В своей статье О развитии революиионных идей в России (1851) А. И. Герцен посвящает Чаадаеву ряд эмоциональных страниц. Так, он писал о первом Философическом nисьме: «Статья эта была встречена воплем скорби и изумления; она испугала, она глубоко задела даже тех, кто разделял симпатии Чаадаева, и все же она лишь выразила то, что смутно волновало душу каждого из нас. Кто из нас не испытывал минут, когда мы, полные гнева, ненавидели эту страну, которая на все благородные порывы человека отвечает лишь мучениями, которая спешит нас разбудить лишь затем, чтобы подвергнуть пытке? Кто из нас не хотел вырваться навсегда из этой тюрьмы, занимающей четвертую часть земного шара...?». И далее: «Письмо Чаадаева прозвучало подобно призывной трубе; сигнал был дан, и со всех сторон послышались новые голоса; на арену вышли молодые бойцы, свидетельствуя о безмолвной работе, проводившейся в течение этих десяти лет». А. И. Герцен, О развитии революиионных идей в России (перевод), в: А. И. Герцен, Собрание сочинений в 30-ти томах, т. 7, Москва 1956, с. 222-223. В 1842-1847 гг. Чаадаев и Герцен довольно тесно общались; сохранилась их переписка. 
понимание преимуществ европейского уклада и даже не предполагали реальных путей соединения его с русским бытом.

Сошлюсь на О. Э. Мандельштама, который одним из первых сформулировал мысль о том, что Чаадаев создал скорее красивую легенду о Западе, чем трезвый и прозаический его портрет ${ }^{15}$.

В нашем контексте мы говорим о мифологизации Запада, в первую очередь, Европы; о создании образа высокоорганизованной, благоустроенной, стабильной, разумной социально-политической сферы. (Между прочим, стоит напомнить, как Чаадаев был потрясен, когда в превозносимой им благостной Европе начались революции! $\left.{ }^{16}\right)$. Примечательно мнение Ф. Степуна о том, что «к католической церкви Чаадаева влекла [...] прежде всего ее громадная организаторская распорядительность, ее социально-культурная экстенсивность» ${ }^{17}$.

Для того, чтобы подчеркнуть значимость этой мифотворческой линии о прошлом и настоящем Европы, сошлемся для примера на творчество К. Н. Леонтьева, Н. Я. Данилевского, многих западников и славянофилов, специально обращавшихся к этой теме, а также деятелей Серебряного века (достаточно вспомнить, в частности, труд Д. С. Мережковского Атлантида-Европа)...

Итак, Чаадаев добился желаемого общественного результата, Россия «зашумела». Редчайший случай: пророк в своем отечестве

15 В своей ранней статье 1915 г. он писал о Чаадаеве: «Только русский человек мог открыть этот Запад, который сгущеннее, конкретнее самого исторического Запада». И далее: «Чаадаев был первым русским, в самом деле, идейно, побывавшим на Западе и нашедшим дорогу обратно. Современники это инстинктивно чувствовали и страшно ценили присутствие среди них Чаадаева». О. Э. Мандельштам, К статье «Чаадаев». Из ранних редакицй и черновиков, в: О. Э. Мандельштам, Слово и культура, Москва 1987, с. 267-268.

16 Так о революции во Франции 1830 г. Чаадаев пишет Пушкину в вышеупомянутом письме 1831 г. как о «великом перевороте в вещах» материального мира, о «всеобщем столкновении всех начал человеческой природы» и даже о «гибели целого мира»! См. П. Я. Чаадаев, Письма, ор. cit., с. 69.

17 Ф. Степун, П. Я. Чаадаев, в: Чаадаев. Pro et contra. Личность и творчество Петра Чаадаева в оценке русских мыслителей и исследователей. Антология, ред. А. А. Ермичев и др., Санкт-Петербург 1998, с. 372. 
был услышан. Но что дальше? Пути дальнейшего развития России самим философом были намечены маловразумительно, за дело принялись славянофилы и западники, народники и революционеры всех мастей...

К сожалению, со своим собственным философским наследием мыслитель обошелся истинно по-русски небрежно. Философская система, которая в готовом виде была у него в голове, на бумаге осталась представленной в отрывках, лишь в том объеме, который был необходим для сиюминутной пропаганды. Или Чаадаев переоценил свой дар изложения и разъяснения, или злую шутку с ним сыграло стремление соригинальничать в области профессиональной философии.

Миф о Чаадаеве наложил свою печать на посмертную судьбу наследия мыслителя. Память о Чаадаеве, неразрывно спаянная с великими именами Золотого века русской литературы, не исчезала с горизонта филологов, однако философы довольствовались мифами Чаадаева и о нем. В течение почти ста лет [!] собирались в полном объеме, а затем выстраивались в истинной последовательности его Философические письма. Непосредственный душеприказчик Чаадаева, М. И. Жихарев сумел только сохранить архив и передать его в Румянцевский музей. А другой дальний родственник, Д. Н. Шаховской уже в середине XX в. извлек архив из библиотечной пыли, разобрал и, наконец, расположил все 8 писем в нужном порядке. Мифологизация творческого образа Чаадаева продолжилась и на этапе его исследования. Многозначительный и даже символический характер имеет история с приписыванием Чаадаеву так называемого «мистического дневника» Д. Облеухова! ${ }^{18}$ Для мифа

18 Впервые по-настоящему исследуя философский архив П. Я. Чаадаева и готовя первую монографию о его творчестве, М. О. Гершензон обнаружил в бумагах мыслителя выдержки из книги Юнг-Штиллинга Приключения по смерти с комментариями. Он ошибочно, вслед за М. И. Жихаревым и А. Н. Кирпичниковым, приписал эту тетрадь Чаадаеву. Позже, переведя с французского, включил этот текст, под названием Мистический дневник, в двухтомное собрание всех известных на тот период произведений П. Я. Чаадаева Сочинения и письма (Санкт-Петербург 1913-1914). 
о басманном отшельнике, да еще объявленном сумасшедшим, «мистический дневник» был как раз кстати. Однако будет большой ошибкой отбросить все размышления введенного в заблуждение М. О. Гершензона. Дневник был, действительно, не Чаадаева, но ведь инспирирован-то он был именно им! Облеухов увлекся мистическими идеями благодаря их длительным дружеским беседам на эти темы, и именно Чаадаев вручил своему единомышленнику книгу Юнг-Штиллинга и даже дал ему некое задание, зная, что добросовестный Облеухов обязательно его исполнит! Но саму мистическую философскую линию Чаадаева нам только предстоит воспроизвести...

Долгая заброшенность философского наследия Чаадаева сказывается и в сложном восстановлении самых необходимых имен и фактов. Так, до сих пор некоторые современные исследователи путают двух мемуаристов - Сергея Николаевича и Михаила Ивановича Жихаревых. А также ученика Чаадаева Ивана Максимовича Ястребцова с писателем Иваном Ивановичем Ястребцовым.

Итак, на настоящий момент мы можем констатировать следующее.

1. П. Я. Чаадаев - первый профессиональный русский философ, полностью посвятивший себя философским изысканиям. Как Кант, Гегель или Шеллинг, он на годы принял своеобразное философское анахоретство, при этом в социальном плане целеустремленно, хоть и весьма своеобразно утверждался в качестве влиятельного мыслителя. В отличие от других современных ему русских философов, писавших «по случаю» или «между делом», уделявших основное время охоте, домашнему хозяйству или литературному труду, публицистике, религиозной или общественной деятельности, Чаадаев всецело посвятил свою жизнь философскому творчеству и распространению своих идей.

2. Чаадаев очевидным образом претендует на обладание целостной оригинальной философской системой, выстроенной на религиозно-мистической основе. В своих работах, не являющихся 
систематическими трудами, он приводит суждения уже с некоторой как бы заранее обусловленной позиции, которая для него является чем-то самим собой разумеющимся.

Для «стороннего» читателя - современника, не имевшего с философом предварительных бесед и не надеявшегося получить необходимые разъяснения при личной встрече, как и нам, далеким потомкам, не остается ничего другого, как пытаться реконструировать теоретические азы религиозно-философской системы Чаадаева.

Вкратце их можно представить следующим образом:

a) религия является основой человеческого существования, как в личном плане, так и в общечеловеческом масштабе;

б) философия вытекает из религиозного или нерелигиозного мышления, всецело определяясь им, следовательно:

в) различные философские направления и разделы философского знания (гносеология, философия истории, этика, философия искусства и т.д.) всегда базируются на конкретной религиозной основе, не могут быть и не бывают абстрактными, отвлеченными, самостоятельными, объективными;

г) поскольку религия всегда имеет личный характер, связана с глубочайшими персональными переживаниями, то и философия не может не быть личной жизненной практикой, которая, переплетаясь с научными данными, нравственными чувствами и эстетическими впечатлениями, непосредственно определяет судьбу отдельного человека, а в конечном счете - народов и человечества в целом.

3. Чаадаев стал первым русским философом религии и историком религии, и на основе своих энциклопедических познаний и некой собственной теории он выстраивал основы нового религиозно-философского учения христианского толка.

4. Из этого религиозно-философского учения вытекала и историко-философская теория Чаадаева, включавшая и трактовку глобальной роли и миссии России.

В этом пункте мы присоединяемся к мнению В. В. Зеньковского, который считал, что у Чаадаева «его взгляд на Россию совсем не 
стоит в центре его учения, а, наоборот, является логическим выводом из общих его идей в философии христианства» ${ }^{19}$.

5. Вне всякого сомнения, поистине этапным для русского самосознания были идеи Чаадаева в области философии истории, политической философии, теории современной цивилизации. Д. Н. Шаховской писал:

Чаадаев [...] не только поставил очень глубокую проблему, бывшую недоступной его современникам, но вместе с тем в попытке разрешить ее предопределил на 100 лет главное направление русской философской мысли, всю работу русского самосознания. Именно подход к объективной истине через субъективное ее искание - вот как мне [...] мыслится постановка вопроса у Чаадаева и в этом же мне чудится назревающее [...] требование к современной исторической науке 20 .

Здесь, на наш взгляд, стоит внимательно исследовать то, что М. О. Гершензон определил как «социальный мистицизм» Чаадаева. Несмотря на фактическую ошибку с приписыванием «мистического дневника» философу, Гершензон проник в самую суть цельности чаадаевского мировоззрения, органичной взаимосвязи философского, религиозного и социально-исторического его аспектов.

Сегодня предварительно сформулируем это так: социально-реформаторские, цивилизационно-трансформационные и религиозно-обновленческие идеи Чаадаева, твердо стоящие на христианской основе, в значительно большей степени связаны с немецким и шире - с западным мистицизмом, нежели с католичеством, несмотря на его явные симпатии к католичеству. Причем, не современному ему, а скорее - к исторически-рафинированному католичеству, как части европейского мифа-образа.

19 В. В. Зеньковский, История русской философии, т. 1, Paris 1989, с. 162.

20 Д. Н. Шаховской, Письма и замечания (письмо И. М. Гревсу от 30.11.1930), в: Чаадаев. Pro et contra, op. cit., с. 536-537. 
6. Нельзя также обойти и поднятую Чаадаевым проблему соотношения веры и знания, роли, значения и опасности современной науки.

7. Наконец, следует сделать важное примечание к современным исследованиям религиозно-философского наследия Чаадаева. Необходимо помнить, что в своих истоках оно формировалось в александровскую эпоху, в пору глубоких религиозных и религиозно-мистических исканий, а одновременно - появления первых отечественных философов-«любомудров».

Религиозно-философское наследие Чаадаева - это самобытный духовный «александрит», который, как и одноименный природный драгоценный камень, меняет свой цвет в зависимости от освещения. Так и идеи Чаадаева могут несколько менять свой смысл в зависимости от того, в каких «лучах» они рассматриваются: в теоретически-философских, богословских или религиозно-мистических. И каждый «цвет» - не иллюзия, не обман зрения, а лишь одна из граней цельного и сложного мировоззрения Чаадаева.

Таким образом, религиозная философия Чаадаева, с оригинальностью ее формы, многосложностью идей, многоуровневостью своих построений и провидческим пафосом для современных историко-философских исследований представляет собой один из наиболее плодотворных творческих проектов, лежащих в основе основ русской философской традиции. Именно с обсуждения чаадаевских идей отечественная религиозно-философская мысль для самих русских философов и богословов стала в один ряд с немецким идеализмом, французским просвещением, европейской философией религии, философией жизни, философией истории...

Подчеркну напоследок, что исследование чаадаевского творческого наследия для современных историков философии - это именно проект, своеобразная реконструкция системы воззрений Чаадаева. Его реализация сегодня возможна на базе собранного нашими предшественниками и достаточно проработанного полного корпуса работ мыслителя и других необходимых материалов. Подлинно философское исследование возможно сегодня, когда 
выявлены и преодолены откровенные ошибки и заблуждения относительно приписываемых Чаадаеву или анонимных его произведений. Сегодня можно и нужно отстраниться от историкокультурологических и социально-политических реминисценций, литературно-художественных и наносных религиозно-мистических уклонов, от специфических богословских рассмотрений и от советско-марксистских и рационально-атеистических построений... Хотя можно с уверенностью утверждать, что миф о Чаадаеве и внедренные им в русское национальное самосознание мифы далеко не исчерпаны, и нас ждут еще открытия, удивительные находки и неожиданные выводы нынешних и будущих исследователей чаадаевского наследия.

\section{Библиография}

Герцен А. И., О развитии революиионных идей в России (перевод), в: А. И. Герцен, Собрание сочинений в 30-ти тт., т. 7, Москва 1956, с. 133-263.

Гершензон М. О., П. Я. Чаадаев. Жизнь и мыциление, Санкт-Петербург 1908.

Зеньковский В. В., История русской философии, т. 1, Paris 1989.

Комментарии и примечания, в: П. Я. Чаадаев, Полное собрание сочинений и избранные письма, т. 2, Москва 1989, с. 283-409.

Лебедев А. А., Чаадаев, Москва 1965.

Ленин В. И., Памяти Гериена, в: В. И. Ленин, Полное собрание сочинений, т. 21, Москва 1967, с. 255-262.

Мандельштам О. Э., К статье «Чаадаев». Из ранних редакиий и черновиков, в: О. Э. Мандельштам, Слово и культура, Москва 1987, с. 268-269.

Проскурина В. Ю., Примечания, в: П. Я. Чаадаев, Сочинения, Москва 1989, c. 566-636.

Степун Ф., П. Я. Чаадаев, в: Чаадаев. Pro et contra. Личность и творчество Петра Чаадаева в оценке русских мыслителей и исследователей. Антология, ред. А. А. Ермичев и др., Санкт-Петербург 1998, с. 370-374.

Тарасов Б. Н., «Тайна человека» и тайна истории. Непрочитанный Чаадаев, Москва 2012. 
Тарасов Б. Н., Чаадаев, Москва 1990.

Чаадаев П. Я., Нечто из переписки NN., «Телескоп» 11 (1832), с. 347-357.

Чаадаев П. Я., Письма, в: П. Я. Чаадаев, Полное собрание сочинений и избранные письма, т. 2, Москва 1991, с. 6-282.

Чаадаев П. Я., Философические письма, в: П. Я. Чаадаев, Полное собрание сочинений и избранные письма, т. 1, Москва 1991, с. 320-440.

Шаховской Д. Н., Письма и замечания (письмо И. М. Гревсу от 30.11.1930), в: Чаадаев. Pro et contra. Личность и творчество Петра Чаадаева в оценке русских мыслителей и исследователей. Антология, ред. А. А. Ермичев и др., Санкт-Петербург 1998, с. 535-537. 